\title{
REPORT ON THE SNOW SURVEY OF GREAT BRITAIN FOR THE SEASON I 948-49
}

By E. L. Hawke and D. L. Champion

THIS report is again primarily based on the data furnished by some I 35 voluntary observers working on behalf of the Society. They contribute in each month from September to May daily statistics of snowfall and snow cover within visual range at well distributed sites representative of the principal climatic regimes in Great Britain. An important supplement to this material comes, through the courtesy of Sir Nelson K. Johnson, Director of the Meteorological Office, Air Ministry, from day-to-day observations of the state of the ground at about r ro of the official stations which supply regular returns to the department's serial publications-The Daily Weather Report, The Weekly Weather Report and The Monthly Weather Report.

Further sources of information are the diaries, notes and log-books of travellers and climbers, on whose co-operation the Survey chiefly depends for knowledge of the extent to which the higher mountains harbour snow during the summer months. Special reference must be made on this occasion to the work of the Durham University Exploration Society, whose members undertook the valuable study of snow conditions in the Cairngorms during July I 949 summarized on page 366 . To all who have collaborated-the able corps of private observers, the Director of the Meteorological Office, his staff at Harrow and Edinburgh and the explorers both corporate and individualthe officers responsible for the conduct of the Society's Snow Survey express their most cordial thanks.

E. L. H.

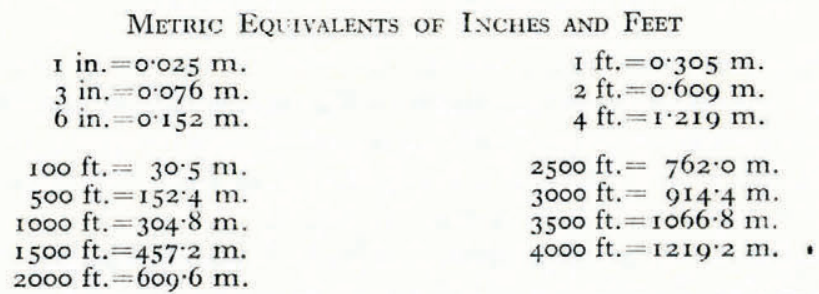

In general measurements of snow-depth cited in this Report refer to ogoo h. G.M.T., or thereabouts.

SEPTEMBER 1948

The month was mild and abnormally wet, particularly in the western highlands of Scotland. Snowfall was confined to slight showers in the north of Scotland on the 2oth and 2Ist. On the $22 n d$ snow was reported lying down to $2000 \mathrm{ft}$. at Blaircreich, Perthshire, and at $2500 \mathrm{ft}$. on the Cuillins, Isle of Skye.

OCTOBER 1948

This month was mild until the $25^{t h}$ and very wet in the west of Scotland. Snow lay down to below $2500 \mathrm{ft}$. on the Fannich Hills, Sutherland on the $I 4 t h$ and $I 5 t h$ and at $2000 \mathrm{ft}$. on peaks in the Cairngorms on the I8th. During the early hours of the 25 th a vigorous depression passed north-eastwards across the north of Scotland, and the cold air stream in its rear gave considerable local snowfalls in Scotland and lighter falls farther south. Snow lay down to sea level in the Shetland Islands from the $26 t h$ to $29 t h$, at Fort William on the $26 t h$, and to station level at Balmoral on the 29th. Snow cover was 3 in. deep at $490 \mathrm{ft}$. at Ardross, Ross-shire on the 26th and was reported at several stations below $500 \mathrm{ft}$. in Sutherland, the Orkney Islands and the Isle of Skye.

In England snow lay occasionally at several places in the north, but none appears to have lain south of the Pennines. On the 26 th snow cover was reported down to below $1500 \mathrm{ft}$. from Eggleston, 
Durham, and Chew Mount, Yorkshire, and an isolated snow shower occurred as far south as Princetown, Dartmoor ( $1359 \mathrm{ft}$.). On the 27 th and 28 th snow lay down to below $1000 \mathrm{ft}$. at High Close, Ambleside, Westmorland.

In Wales the snow cover was down to under $500 \mathrm{ft}$. on the Caernarvonshire mountains on the $26 t h$, and to between $500 \mathrm{ft}$. and $2000 \mathrm{ft}$. on the Brecon Beacons on the $28 \mathrm{th}$.

\section{NOVEMBer 1948}

The weather of this month was abnormally dry and mild, consequently the snowfall was for the most part slight and confined to the higher ground in the north. In Scotland snow lay below $1000 \mathrm{ft}$. in the Shetland Islands on the 5 th and 6 th, below $1500 \mathrm{ft}$. in the Orkney Islands and in the Sutherland and Ross-shire Hills from the 4 th to $8 t h$, and below $2500 \mathrm{ft}$. in the Cairngorms. On the 6 th the cover lay below $1500 \mathrm{ft}$. in the Braes of Glen Livet, Banffshire, and on the Cuillins.

In England snow lay down to between 2500 and $3000 \mathrm{ft}$. on the Furness Fells on the 6 th, and in Wales a light cover down to $3000 \mathrm{ft}$. was reported on Snowdon on the 8 th.

\section{DECEMBER 1948}

The month was generally mild and stormy, and apart from scattered showers, heavy locally in Scotland, little snow fell until the end of the month. On the 27 th a cold front, associated with an intense depression moving north-eastwards over Iceland, crossed the British Isles and the Arctic air in its rear gave considerable snowfalls in the north and west.

On the 27 th to $3 I s t$ the snow line was down to $840 \mathrm{ft}$. at Whitchester, Berwickshire, and on the $30 t h$ and 3 Ist was below $500 \mathrm{ft}$. in parts of Ross-shire, Nairnshire and at Mauchline, Ayrshire; in Glen Lyon, Perthshire, the snow lay 3 in. deep at $760 \mathrm{ft}$. on the 3Ist. In Glenshiel, Ross-shire, the cover was $8 \mathrm{in}$. deep at $500 \mathrm{ft}$. on the $3 I$ st. On the other hand, no snow was observed in the Orkney or Shetland Islands, and only slight showers were reported in North Uist, Outer Hebrides. It is of interest to note that the first snow cover of the season at Dalwhinnie, Inverness-shire ( 1 i $76 \mathrm{ft}$.) did not occur until the 30 th.

In England, the Pennines generally were snow covered down to the rooo- $\mathrm{ft}$. level from the 28 th onwards, and the snow-line fell to below $500 \mathrm{ft}$. in the Lake District and Furness Fells on the 28 th. On the $30 t h$ snow lay 12 in. deep at Wirksworth, Derbyshire, 8 in. deep at Mansfield, Nottinghamshire, and 6 in. deep as far south as Shawbury, Shropshire. On this day the snow cover was 6.5 in. deep on level ground and 18 in. deep in drifts at Chew Mount ( $1500 \mathrm{ft}$.). Slight snow showers were reported on the 29 th and $3^{I}$ st at Ulverscroft, Leicestershire, and on the latter date "snow lying" was reported at 1359 ft. at Princetown, Dartmoor. East Anglia and the southern counties generally were snow-free throughout the month.

In Wales the snow-line was down to $500 \mathrm{ft}$. or lower on most of the mountains in the northern and central counties on the 30 th and 3 Ist, there being a depth of 3 in. with drifts up to $2 \mathrm{ft}$. 6 in. deep at Bwlch Tunnel, Denbighshire. The snow cover was down to below $1000 \mathrm{ft}$. on the Brecon Beacons, but at Crickhowell, in this area, no snow was reported.

D. L. C.

\section{JANUARY 1949}

The first month of 1949 was predominantly mild. Except at a few stations in the far north of Scotland and in the Hebrides mean temperature was everywhere above normal, the general excess over the average amounting to $2 \cdot 1^{\circ} \mathrm{F} .\left(\mathrm{I} \cdot 2^{\circ} \mathrm{C}\right.$.) in England and Wales and $\mathrm{I} \cdot 4^{\circ} \mathrm{F} .\left(0 \cdot 8^{\circ} \mathrm{C}\right.$. $)$ in Scotland. Large areas England and South Wales and various lowland districts of eastern Scotland were wholly free from snow or sleet, and away from the mountains snow cover lasting continuously for a week or more was rare. The chief spell of wintry weather occurred early in the month. On the Ist an exceptionally deep depression travelled eastward across Ireland and thence to a position off the west coast of Norway by the morning of the 3 rd. On the 4 th another disturbance of less 
intensity passed from north-west Ireland to East Anglia. Behind both these systems air of Arctic origin engulfed most of Britain and widespread snowfalls resulted, the heaviest of them at low and moderate levels coming to western Scotland. At Glenshiel (500 ft.) snow lay to a depth of $\mathrm{I}_{2}$ in. on the $2 n d$ and 4 th and $\mathrm{I}_{3}$ in. on the $3 r d$. Residual drifts persisted there for the rest of the month. Similar depths were reported from a few upland stations in northern England-e.g. at $1000 \mathrm{ft}$. near Bacup, Lancashire, on the $4 \mathrm{th}$, where drifting to $4 \mathrm{ft}$. was produced by high winds. Elsewhere, at levels of $200 \mathrm{ft}$. and above, depths of 3 in. to 8 in. were common about this time. As far south as Dartmoor (Princetown, $1359 \mathrm{ft}$., and Tavistock, $457 \mathrm{ft}$.) the ground was covered 6 in. deep on the morning of the $3 r d$, but most of the accumulation disappeared within 24 hours. On the 6 th all the islands of the Inner Hebrides were reported to be under snow : at Colonsay, Inner Hebrides, a layer 5 in. to 6 in. thick remained on the ground for four or five days. South-east of a line from the Wash to the Severn estuary the snowfalls were localized and appreciable depths were uncommon, even on the hills; 2 in. at Downe ( $560 \mathrm{ft}$.), Kent, on the 2 nd was outstanding.

After the close of the first week there was no recurrence of widely distributed snow, though from the 8 th to 12 th and again around the $20 t h$ short-lived incursions of Arctic air brought sporadic falls, particularly in the north and west of Scotland. Glen Livet (1050 ft.) had 2 in. lying on the I2th and 2.5 in. on the $2 I s t$; Auchintoul ( $420 \mathrm{ft}$.), Sutherland, 4 in. on the IIth and $\mathrm{r} \cdot 5$ in. on the $I 9$ th ; Aviemore (ro5o ft.), Inverness-shire, 4 in. on the $20 t h$ and $2 I s t$, with drifts to $4 \mathrm{ft}$. at $1500 \mathrm{ft}$. ; Glenshiel ( $500 \mathrm{ft}$.), 4 in. on the $12 \mathrm{th}$. In Wales, Bwlch Tunnel ( $900 \mathrm{ft}$.), Denbighshire, reported 2 in. on the IIth. Among the few English stations to experience a cover after the 7 th were Barnt Green $(640 \mathrm{ft}$.), Worcestershire, with $0.5 \mathrm{in}$. on the 12 th, and West Bromwich ( $543 \mathrm{ft}$.), Staffordshire, with 0.7 in. also on the $22 \mathrm{th}$. On the same morning there were light coatings farther south-at Whipsnade (720 ft.), Bedfordshire, and Downe ( $560 \mathrm{ft}$.).

In the Scottish Highlands, the Fannich Hills had a snow cover to below $2500 \mathrm{ft}$. and Ben Wyvis to below $3000 \mathrm{ft}$. throughout the month. The Cuillins were covered to below $3000 \mathrm{ft}$. until the 22nd.

The number of days giving snow or sleet at low or moderate levels (less than rooo ft.) exceeded Io only in central and northern Scotland, where it reached 19 at Strathy ( $120 \mathrm{ft}$.), Sutherland, I 5 at Baltasound ( $3 \mathrm{I} \mathrm{ft}$.), Shetland Islands, 13 at Hatston ( $35 \mathrm{ft}$.), Orkney Islands, and 12 at Wick ( $19 \mathrm{ft}$.), Caithness. The maximum frequencies of snow cover at stations below $5_{500} \mathrm{ft}$. were

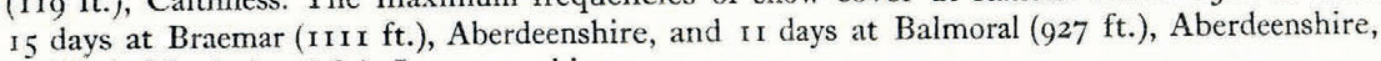
and Dalwhinnie ( $1176 \mathrm{ft}$.), Inverness-shire.

\section{FFBRUARY 1949}

This was another mild month. For Britain as a whole the mean temperature exceeded the average by about $2 \cdot 5^{\circ} \mathrm{F}$. ( $1 \cdot 4^{\circ} \mathrm{C}$.). Over the southern half of England and in South Wales snow was limited to occasional scattered showers, chiefly on the $8 t h, 9 t h, I 2 t h$ and $27 t h$, and no cover was reported, even at stations above the $700 \mathrm{ft}$. level. In northern England and North Wales the falls, though more widely distributed than in the south, were infrequent and mostly light, deposits of as much as 3 in. being rare below $1500 \mathrm{ft}$. Higher up, a depth of 6 in. with 18 -in. drifts in sheltered hollows, occurred at 2800 to $3000 \mathrm{ft}$. on Helvellyn and Fairfield Tops on the I2th. In Scotland several observers commented on the scarcity of snow. While many of the mountains had their usual February coating all through the month, the snow-line was often abnormally high; on Ben Nevis it was above $3000 \mathrm{ft}$. from the $15^{t h}$ to $19 \mathrm{th}$. In the Isle of Skye, the Cuillins at $3000 \mathrm{ft}$. appear to have been without a 50 per cent cover until the 7 th and from the $I 6$ th to $2 I s t$.

Among the grestest depths of snow reported from stations below $1000 \mathrm{ft}$. on the Scottish mainland were 4 in. at Glenshiel ( $500 \mathrm{ft}$.) on the 8 th and at Fort William ( $34 \mathrm{ft}$.), Inverness-shire, on the $9 t h, 4.5$ in. at Auchintoul ( $420 \mathrm{ft}$.) on the $27 t h$, and 6 in. or more at Balmoral ( $927 \mathrm{ft}$.) also on the $27 \mathrm{th}$. Above $1000 \mathrm{ft}$. the depth of the cover reached or exceeded 6 in. at Dalwhinnie ( $1176 \mathrm{ft}$.) 
from the $22 n d$ to $24 t h$, as well as on the $27 t h$ and $28 t h$; at Braemar ( 1 I I I ft.) on the $27 t h$ and $28 t h$. Long stretches of the Perth-Inverness road lay under about 9 in. of snow at this time. Among the contributing stations Auchintoul (420 ft.) had the greatest number of days with observed snow or sleet-13; next came Elphin (700 ft.), Sutherland and Glen Livet (ro5o ft.) with 12 each. For frequency of "snow lying" Dalwhinnie ( 1 r $76 \mathrm{ft}$.) headed the list with 8 days.

\section{MARCH I949}

Over the greater part of Britain this month proved to be a little colder than usual, and its first fortnight brought the principal snow spell of the 1948-49 season. Although the falls during that period affected at least three-quarters of the country's total area, and occurred frequently in many districts, nowhere were they anything out of the ordinary. The snow came chiefly with northerly winds, blowing at times with gale force, behind successive eastward-moving troughs of low pressure. Average depths of 6 in. or rather more were fairly common at intervals until the 9 th at the 400 to $1000 \mathrm{ft}$. levels in Scotland and the northern half of England. They were also reported from Lerwick ( $259 \mathrm{ft}$.), Shetland Islands, on the $r s t$ and $2 n d$. An outstanding measurement was one of 8 in. at High Close ( $553 \mathrm{ft}$.), Westmorland, at $6_{3} \circ \mathrm{h}$. G.M.T. on the 5 th.

In the southern half of England and over nearly the whole of Wales depths of as much as 4 in. do not appear to have accumulated below the rooo ft. level, and even at that height were never at all general. There was, however, a good deal of drifting in exposed localities. On Broadway Hill (ro $48 \mathrm{ft}$.), Worcestershire, the road was blocked after a 4 in. fall on the 5 th to 6 th by long drifts about $3 \mathrm{ft}$. deep, some of which did not entirely melt away until the $23 \mathrm{rd}$.

After the $14 t h$ snow was mainly confined to occasional showers in the northern uplands, though on the I8th and Igth these extended to the Chiltern Hills and some of the low hills in East Anglia and Kent.

In the Scottish Highlands, a snow cover persisted to below $3000 \mathrm{ft}$. throughout the month on Ben Wyvis and the Fannich Hills. On Ben Nevis, however, only patches of snow were observed to be lying below the $3000 \mathrm{ft}$. level after the Igth. Hoy Hills, in the Orkney Islands, were coated to below $1500 \mathrm{ft}$. on $\mathrm{x} 6$ of the first 20 days; the Brecon Beacons to below $2500 \mathrm{ft}$. from the 6 th to I4th. On the $I_{5}$ th an ice-axe was needed for the ascent of some of the peaks near Ullswater and occasional cornices were found on Helvellyn. A striking insolation effect was reported from the Furness Fells on the IIth: southward-facing slopes at about $2500 \mathrm{ft}$. had less than 50 per cent snow cover, whereas hillsides at 500 to $1000 \mathrm{ft}$. facing north were completely white.

Among stations at low and moderate levels (less than rooo ft.) the largest number of days with falls of snow or sleet was 17 at Lerwick; Auchintoul followed with $\mathrm{I}_{5}$ and Hatston with $\mathrm{I}_{3}$; the maximum frequencies for days with snow lying below the same limit were, in Scotland, 8 at Lerwick and Craibstone ( $300 \mathrm{ft}$.), Aberdeenshire; in England and Wales, 7 at Houghall ( $160 \mathrm{ft}$.), Co. Durham, and Belmont, Bolton ( $800 \mathrm{ft}$.), Lancashire. There was entire absence of snow or sleet in North Uist (Outer Hebrides), at Colonsay and at Mauchline as well as in the Isle of Man and many parts of southern Scotland and South Wales.

\section{APRIL I949}

Notably genial weather marked this month over most of Britain. The mean temperature exceeded the average by $4 \cdot 3^{\circ} \mathrm{F}$. $\left(2 \cdot 4^{\circ} \mathrm{C}\right.$.) in England and Wales and by $3 \cdot 2^{\circ} \mathrm{F}$. ( $1 \cdot 8^{\circ} \mathrm{C}$.) in Scotland, where the extreme minimum, $26^{\circ} \mathrm{F} .\left(-3.3^{\circ} \mathrm{C}\right.$. $)$, at Lerwick, Balmoral and Glen Livet on the $8 t h$, had been under-passed in every previous April back to I 864 . There were, however, brief cold spells between the 5 th and Ioth and from the $20 t h$ onwards : with these was associated occasional fairly widespread snow of the characteristic showery April type. In the Scottish Highlands substantial falls occurred at high levels on the 6 th and $7 t h$, a fresh deposit of 12 in. being reported from the area of the Cairngorms above $3000 \mathrm{ft}$. Ben Wyvis was coated to below $3000 \mathrm{ft}$. from the 
5 th to IIth and again from the 20 th to $30 t h$, and to below $1500 \mathrm{ft}$. on the 5 th, 7 th and $22 n d$. On the Fannich Hills a continuous cover was observed at below $3000 \mathrm{ft}$. from the 4 th onwards; under the influence of mild Atlantic winds the snow-line in that district rose steadily from base level on the 8 th to between 2500 and $3000 \mathrm{ft}$. on the $I 3 \mathrm{th}$. In the Isle of Skye, the Cuillins were under snow to below $2500 \mathrm{ft}$. from the 7 th to $10 t h, 20 t h$ to $24 t h$, and on the $28 t h$.

In northern England, Kinder Scout was "thickly covered" between 1500 and $2000 \mathrm{ft}$. on the morning of the $8 t h$. At levels below rooo ft. in Scotland, Glenferness (700 ft.), Nairnshire, had 3 in. on the $7 t h$, but with that exception no depth greater than 2 in. was reported. In Wales, the Caernarvonshire heights and Cader Idris were coated to under $2000 \mathrm{ft}$. on the 7 th and $8 t h$, and the Brecon Beacons at $2900 \mathrm{ft}$. from the 8 th to $I$ Ith.

On the lower ground in the southern half of England and in South Wales there were only light scattered showers of sleet or snow during the short cold spells.

On the 22nd a small party making the ascent of Ben Nevis were swept down some $1500 \mathrm{ft}$. by an avalanche (probably the result of a loosened cornice) from near the top of the Gardy Loo gully and narrowly escaped with their lives.

\section{MaY 1949}

This was a month of approximately normal mean temperature over Britain as a whole. Except on the mountains in Scotland, northern England and North Wales there was very little snow. The Fannich Hills were covered to below $3000 \mathrm{ft}$. until the 19 th and again on the 26 th to $28 \mathrm{th}$; from the 20 th to 25 th and 29th to 3 Ist observations could not be made. On the Cuillins snow lay to below $2500 \mathrm{ft}$. from the 5 th to 8 th and to below $1000 \mathrm{ft}$. on the 6 th. In Wales, Carnedd Llewelyn had a light coating above $2500 \mathrm{ft}$. on the 5 th and 6 th. About this time showers of sleet or snow were not uncommon at low levels in central, eastern and northern Scotland. They were reported also at stations above $700 \mathrm{ft}$. in the West Riding of Yorkshire, in Lancashire, and on the Cotswold Hills. Locally in Scotland there was a recurrence of slight snow showers from the 28 th to 30 th.

\section{SUMmer, 1949}

Through the courtesy of the Durham University Exploration Society we are able to present a summary of snow observations made during July in the upper Cairngorms by a party of its members who maintained a camp and a small meteorological station a few hundred feet below the summit of Ben Macdhui. In all, some 35 snow-patches were surveyed and measured for area within the region bounded by the River Dee to the south, Beinn A'Bhuird to the east and Loch Einich to the west. They consisted for the most part of wet snow which in many instances overlay masses of white or blue-white ice. Noteworthy in view of the warm spring and summer were the following: $(a)$ a group of ten large patches at about the $3900 \mathrm{ft}$. level on the east-facing slope of Ben Macdhui; on fuly IIth these were of rapidly thawing snow with no discoverable ice beneath and embraced a total area of approximately 120,000 square yards (100,000 square meters); (b) two patches (slushy snow above white ice) occupying on Fuly IIth 50,000 square yards $\left(42,000 \mathrm{m.}^{2}\right)$ at an altitude of about $375^{\circ} \mathrm{ft}$. east of Cairn Lochan (Cairn Gorm district); aspect east-south-east; $(c)$ two patches of similar constitution with a combined area of 100,000 square yards $\left(84,000 \mathrm{~m} .{ }^{2}\right)$ on fuly 24 th located on the slopes overlooking Garbh Uisge in the same district; aspect east, altitude about $375^{\circ} \mathrm{ft}$; $(d)$ five patches extending in all over 40,000 square yards $\left(33,000 \mathrm{~m} .{ }^{2}\right)$ on $\mathcal{F u l y}_{2} 2 \mathrm{th}$ on An Garbh Choire (Braeriach district), aspect east, altitude $3500 \mathrm{ft}$. to $3900 \mathrm{ft}$. All the patches examined, except those on Braeriach, were at a low angle of slope. No snow was observed in any of the north-facing corries along the northern margins of the Cairngorms. Few measurements of depth were made, but one Cairn Gorm patch occupying a steep-sided valley opening to the east appeared to be "very deep in the centre" on fuly $24 t h$. In general, the accumulations of snow and ice were reported to be shallow and unlikely to survive the summer should ablation be maintained at the same rate as in July. 
From fuly Ioth to 28 th the party carried out daily measurements of ablation in a snow-patch at about $3800 \mathrm{ft}$. near the camp beneath the summit of Ben Macdhui, a set of graduated poles hammered vertically into the snow being used for this purpose. Over the period of the observations ablation * totalled 63.9 in. The average decrease in the depth of the snow was thus 3.55 in. per day, but there was a fairly wide range of variation. Below we give the two largest and the two smallest daily values, with readings of air temperature as recorded in a portable louvred thermometer screen set up at a height of $3 \mathrm{ft}$. above the ground close by the camp. Notes on weather, wind, relative humidity and rainfall are appended.

\begin{tabular}{|c|c|c|c|c|c|c|c|c|}
\hline \multirow{2}{*}{ Dates 1949} & & \multirow[b]{2}{*}{ Ablation } & \multicolumn{6}{|c|}{ Temperature } \\
\hline & & & \multicolumn{2}{|c|}{$\begin{array}{l}\text { Mean of readings at } \\
9 h ., 15 h . \text { and } 2 \mathrm{r} h . \text { on } \\
\text { first date }\end{array}$} & \multicolumn{2}{|c|}{ Max. on first date } & \multicolumn{2}{|c|}{ Min. on second date } \\
\hline $\begin{array}{l}\text { July } 22 \text { nd }-23 \text { rd } \\
\text { July Ioth-1 Ith }\end{array}$ & : & $\begin{array}{l}\text { in. } \\
6 \cdot 7 \\
6 \cdot 4\end{array}$ & $\begin{array}{l}{ }^{\circ} F \\
54 \\
60\end{array}$ & $\begin{array}{l}{ }^{\circ} \mathrm{C} . \\
12 \cdot 2 \\
{ }_{15} \cdot 6\end{array}$ & $\begin{array}{l}{ }^{\circ} F \\
65 \\
74\end{array}$ & $\begin{array}{l}{ }^{\circ} C . \\
18 \cdot 3 \\
23 \cdot 3\end{array}$ & $\begin{array}{l}{ }^{\circ} F \text {. } \\
5 \circ \\
53\end{array}$ & $\begin{array}{l}{ }^{\circ} \mathrm{C} . \\
10 \cdot 0 \\
11 \cdot 7\end{array}$ \\
\hline $\begin{array}{l}\text { July } 19 \text { th-2oth } \\
\text { July } 16 \text { th- } 17 \text { th }\end{array}$ & : & $\begin{array}{l}r \cdot 0 \\
\mathrm{I} \cdot 2\end{array}$ & $\begin{array}{l}42 \\
37\end{array}$ & $\begin{array}{l}5 \cdot 6 \\
2 \cdot 8\end{array}$ & $\overline{42}$ & $\overline{5 \cdot 6}$ & $\begin{array}{l}38 \\
34\end{array}$ & $\begin{array}{l}3 \cdot 3 \\
\mathrm{I} \cdot \mathrm{I}\end{array}$ \\
\hline
\end{tabular}

Notes.-Fuly 22nd: hill fog morning and evening, occasional drizzle, sunny periods; light to moderate southerly or variable winds; relative humidity roo per cent at $9 \mathrm{~h}$., $\mathrm{I}_{5} \mathrm{~h}$. and $2 \mathrm{Ih}$.; rainfall 0.02 in. Fuly $23 \mathrm{rd}$ : hill fog, thin drizzle and occasional light showers of rain morning, sunshine afternoon, hill fog evening ; calm to light variable breezes; relative humidity roo per cent at $9 \mathrm{~h}$. and $2 \mathrm{rh} ., 88$ per cent at $\mathrm{I} 5 \mathrm{~h}$.; rainfall trace. Fuly roth: fine throughout, patches of hill fog evening; wind moderate southerly, becoming light and variable, then moderate northerly; relative humidity $6 \mathrm{I}$ per cent at $9 \mathrm{~h} ., 54$ per cent at $\mathrm{i} 5 \mathrm{~h} ., 93$ per cent at $2 \mathrm{rh}$.; rainfall trace; an abnormally warm day for the Highlands; air temperature reached $82^{\circ} \mathrm{F}$, at Balmoral; the $74^{\circ} \mathrm{F}$. registered near the summit of Ben Macdhui was probably exceptional at that altitude. Fuly IIth: intermittent drizzle, bright periods, hill fog in evening; light west-north-west breeze; relative humidity 97 per cent at 9 h., 93 per cent at 15 h., 96 per cent at 21 h.; rainfall 0.02 in. Fuly Igth: squally, rain at times, bright periods; strong to moderate northerly winds; relative humidity 85 per cent at $9 h$. and I 5 h., 92 per cent at $2 \mathrm{rh}$.; rainfall 0.07 in. $\mathcal{F}$ uly $20 t h$ : much hill fog, clear periods, heavy drizzle in evening; wind south to south-west, moderate to strong; relative humidity roo per cent at $9 \mathrm{~h} .,{ }_{5} \mathrm{~h}$. and $2 \mathrm{xh}$.; rainfall 0.34 in. Fuly $\mathrm{I} 6 \mathrm{th}$ : hill fog throughout, drizzle at times, bright intervals in afternoon, wind north-north-east, moderate to fresh; relative humidity 100 per cent at $9 \mathrm{~h} ., \mathrm{I}_{5} \mathrm{~h}$. and $2 \mathrm{Ih}$.; rainfall 0.02 in. Fuly I7th: much hill fog and drizzle, bright periods; light north-north-east wind; relative humidity 100 per cent at $9 \mathrm{~h} ., \mathrm{r} 5 \mathrm{~h}$. and $2 \mathrm{rh}$.; rainfall measurement not available.

\section{Summary}

At low and moderate levels throughout Great Britain the $1948-49$ season is considered to have been snow-free to a notable if not exceptional degree. Records from the same ten selected representative stations at altitudes between 400 and $1200 \mathrm{ft}$., five of them in England, one in Wales and four in Scotland, give the following averages for the total number of days with "snow lying" from September to May since the post-war re-institution of the Survey : 1946-47, 66; 1947-48, 26 ; I948-49, 13. Even around the rooo ft. level in the Scottish Highlands the maximum reported frequencies of such days for those nine months of 1948-49 were only 39 at Braemar, and 35 at 
Glen Livet. Over areas comprising some hundreds of square miles in the southern counties of England and in Wales the ground was never so much as half covered by snow at the hour of morning observation, while at numerous stations in the Devon-Cornwall peninsula and the southern half of Wales the entire season was reported to have passed without either snow or sleet. According to the data available, individual snowfalls below rooo $\mathrm{ft}$. were nowhere out of the ordinary, and none seems worthy of being singled out for special comment. The four-day cover at sea-level in the Shetland Islands from October 26th-2gth should perhaps receive mention on account of its earliness; likewise the 3 in. coating at Ardross ( $490 \mathrm{ft}$.) on October 26th. E. L. H.

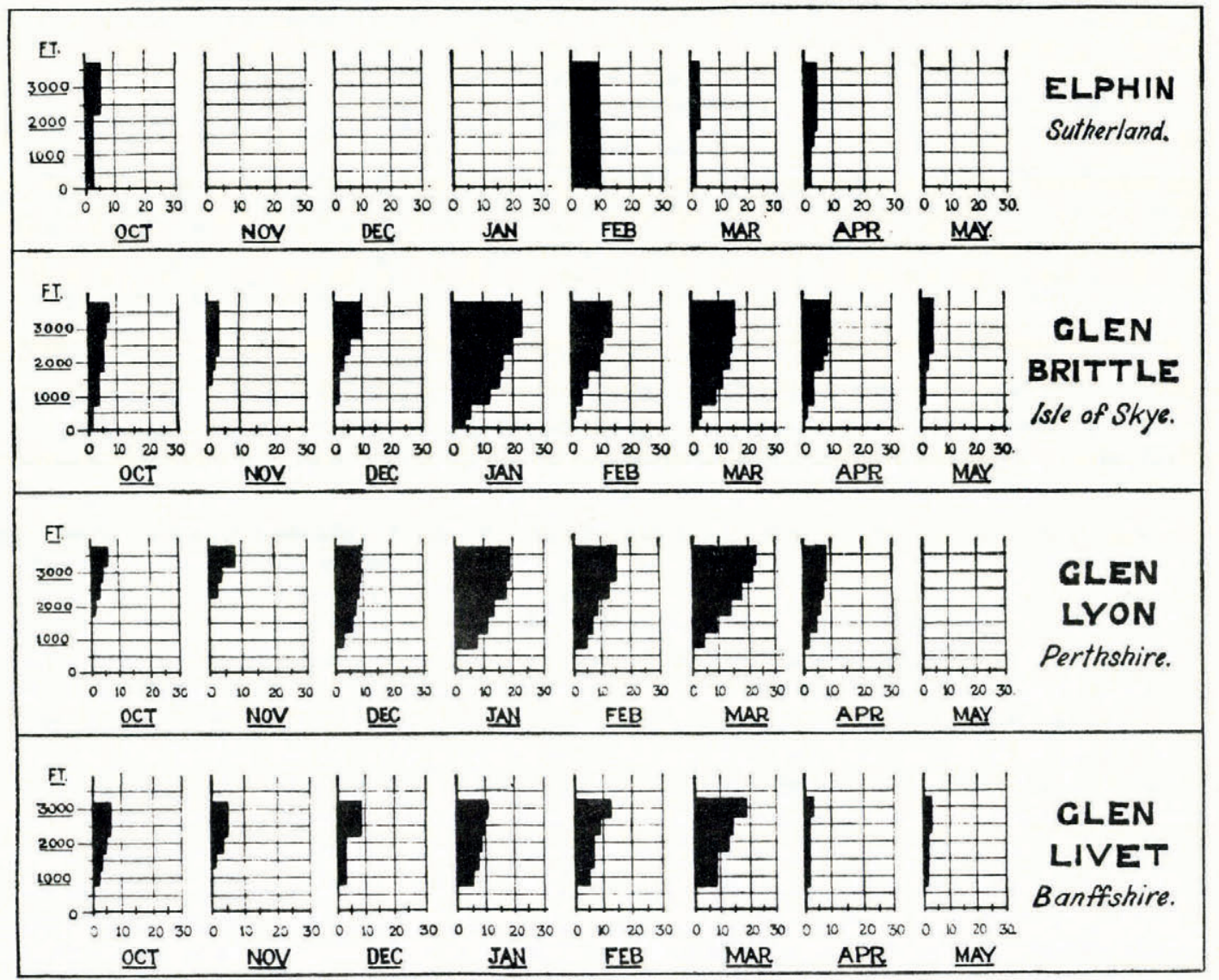

\section{NOTE ON DURATION OF SNOW COVER ON B R I T I H M O U T A I S}

In spite of the remarkably snow-free season, snow cover on our mountains was reported somewhere in every month from September to May, and in October the snow line was down to below $2000 \mathrm{ft}$. at each of the representative stations from Sutherland to South Wales, in marked contrast to the $1947-48$ season when no mountain snow cover was observed in this month. The duration of snow cover in March 1949 considerably exceeded that of March 1948 at all mountain stations. 